\title{
PEMANFAATAN EKSTRAK BUNGA SEPATU (Hibiscus rosa-sinensis L.) SEBAGAI ALTERNATIF PEWARNA ALAMI SEDIAAN SITOLOGI PENGGANTI EOSIN PADA PENGECATAN DIFF-QUICK
}

\author{
Lukmatul Mutoharoh 1), Setyo Dwi Santoso'), Andita Ayu Mandasari ${ }^{1,2)}$ \\ 1)Prodi D3 Teknologi Laboratorium Medik, Fakultas Ilmu Kesehatan, UMAHA \\ ${ }^{2)}$ Penulis korespondensi, Prodi D3 Teknologi Laboratorium Medik, \\ Fakultas Ilmu Kesehatan, UMAHA \\ e-mail : andita_ayu_mandasari@dosen.umaha.ac.id
}

\begin{abstract}
ABSTRAK
Bunga sepatu (Hibiscus rosa-sinensis L.) merupakan tanaman semak kelompok Malvaceae yang berasal dari Asia Timur dan banyak dimanfaatkan sebagai pagar hidup maupun tanaman hias di daerah subtropis dan tropis. Bunga sepatu dulu banyak digunakan sebagai pewarna alami untuk makanan. Bunga sepatu mengandung pigmen warna antosianin. Pemanfaatan antosianin telah banyak dilakukankan salah satunya pewarna produk makanan maupun minuman. Pewarna alami antosianin semakin banyak diminati karena dapat mengurangi penggunaan pewarna sintetik yang memiliki sifat toksik serta tidak ramah lingkungan. Tujuan penelitian ini adalah untuk mengetahui pemanfaatan ekstrak bunga sepatu (Hibiscus rosa-sinensis L.) sebagai pewarna alami pengganti eosin pada pengecatan diff quik. Sampel yang digunaakan untuk membuat sediaan sitologi berasal dari kerokan mukosa bukal. Bagian kelopak bunga sepatu yang diambil dan dikeringakan, kemudian diekstrak dengan pelarut etanol 96\%. Dari hasil penelitian diketahui bahwa sediaan yang dapat terwarnai dengan baik pada konsentrasi ekstrak $0,5 \mathrm{gr} / \mathrm{ml}$ yang ditambahkan $\mathrm{HCl} 1 \%$ dengan waktu perendaman 30 menit. Serta pada konsntrasi ektrak $0,7 \mathrm{gr} / \mathrm{ml}$ dengan waktu perendaman 15 menit sel dapat terwarnai dengan cukup baik.
\end{abstract}

Kata kunci : Hibiscus Rosa sinensis L, sediaan sitologi, pengecatan diff quik.

\section{PENDAHULUAN}

Sitologi merupakan salah satu bidang yang berkaitan dengan ilmu yang mempelajari tentang morfologi sel - sel secara individual atau sel yang berasal dari fragmen jaringan yang diamati secara mikroskropis. Diagnostik atau sitologi klinis merupakan studi tentang penilaian normal maupun tidaknya dari sel yang diperoleh dari berbagai situs tubuh (deteksi karakteristik morfologi abnormal yang dipisahkan dari tubuh manusia). Sediaan sitologi dapat dibuat dari berbagai sumber dalam tubuh (urin, puting, dahak, vagina, sinus, dll), kerokan diperoleh (mukosa bukal, lambung, saluran pernapasan), dan dari cairan yang terkumpul di dalam tubuh (pleura, peritoneal, perikardial) bahkan dari aspirasi benjolan tubuh yang terlihat atau teraba (Khristian \& Inderiati, 2017).

Benar atau tidaknya suatu diagnosis tergantung pada kualitas sediaan sitologi yang dihasilkan. Untuk menghasilkan sediaan sitologi yang baik maka kualitas persiapan materi untuk dijadikan sediaan wajib diketahui dengan benar. Akurasi pemeriksaan sitologi dari bagian bagian tubuh sangat tergantung pada kualitas sediaan, persiapan, pengecatan dan interpretasi dari sediaan itu (Khristian \& Inderiati, 2017).

Salah satu teknik pengecatan dalam sitologi adalah pengecatan dengan metode diff quik. Pengecatan diff quik ialah turunan pewarnaan Romanowsky yang digunakan untuk mewarnai sel yang berasal dari sampel nonginekologi dan darah, termasuk FNAB (Fine 
Needle Aspiration Biopsy). Pengectan ini memiliki selektifitas antara eosinofilik dan pewarnaan basofilik (Lukas, 2016). Komposisi pewarna yang digunakan pada pengecatan diff quik yaitu eosin dan methylen blue.

Eosin merupakan pewarna sintetis yang masuk dalam golongan xanthene. Eosin memiliki sifat asam dan akan mengikat molekul protein yang bermuatan positif disitoplasma dan jaringan ikat. Eosin merupakan counterstain yang dapat mewarnai sitoplasma dan jaringan ikat. Methylene blue merupakan contoh dari pewarnaan kation atau ion positif pada jaringan. Pewarnaan kation disebut juga sebagai pewarnaan basal dan juga disebut sebagai pewarnaan basophilic. Pada umumnya digunakan untuk mewarnai inti sel (Lukas, 2016).

Pada penelitian ini diharapkan dapat mengembangkan pemanfaatan salah satu flora yang dapat digunakan sebagai pewarna yang memiliki sifat yang sama dengan eosin. Bunga sepatu (Hibiscus rosa sinensis $\mathrm{L}$ ) ialah tanaman semak suku Malvaceae yang berasal dari daerah Asia Timur serta banyak di tanam untuk tanaman hias di daerah subtropis dan tropis. Bunga sepatu yang memiliki bunga berwarna merah, selain sebagai tanaman hias, bunga sepatu dimanfaatkan oleh masyarakat sebagai obat untuk batuk, sariawan, demam, dan juga digunakan untuk bahan pewarna. (Siregar \& Nurlela, 2011). Pada bunga kembang sepatu teridentifikasi adanya senyawa golongan, tanin dan fenolik, serta unsur lain zat besi, kalsium, dan fosfor (Sugumaran, Poornima, \& Sethuvani, 2012).

Menurut (Agustin \& Ismiyati, 2015) antosianin pada bunga kembang sepatu dapat diperoleh dengan cara mengekstraksi kelopak bunga kembang sepatu menggunakan pelarut etanol konsentrat yang menghasilkan ekstrak pekat yang berwarna merah keunguan. Pada konsentrasi optimum didapat kandungan antosianin sebesar 48,260 mg/ 25gr kelopak bunga kembang sepatu dengan pembacaan hasil ekstrak menggunakan instrument spektrofotometer pada $\lambda 528 \mathrm{~nm}$.
Beberapa tanaman yang mengandung antosianin telah dimanfaatkan untuk pewarna alami. Bunga rosella (Hibiscus sabdariffa), kembang sepatu (Hibiscus rosa sinensis) dan bunga mawar (Rosa damascena) digunakan sebagai pewarna pada pemeriksaan parasit L.donovani (Kamal, 2018). Selain itu bunga sepatu juga dimanfaatkan sebagai pengganti eosin pada pewarnaan sediaan histopatologi (Sridhara, Raju, Gopalkrishna, \& Haragannvar, 2016).

\section{METODE PENELITIAN}

Metode penelitian yang diterapkan pada penelitian ini adalah percobaan laboratorium yaitu suatu metode untuk mengetahui kemampuan ekstrak bunga sepatu sebagai pengganti eosin pada pengecatan diff quik.

\section{Alat dan Bahan}

Alat yang digunakan untuk penelitian ini yaitu beaker glass, gelas jar, corong kaca, spatula, rak tabung, tabung reaksi, pipet tetes, erlenmayer, objek glass, mikroskop, oven, blender, kertas saring whatman, gelas ukur, neraca analitik, kasa, labu ukur, cytobrush. Sedangkan bahan yang digunakan yaitu kelopak bunga sepatu, etanol $96 \%, \mathrm{NaOH} 10 \%, \mathrm{HCl}$ pekat, $\mathrm{HCl} 1 \%$, metanol, cat diff quik eosin, methylen blue dan akuades.

\section{Persiapan Sampel}

Bunga sepatu dipisahkan dari tangkai bunga dan diambil bagian kelopak bunganya. Kemudian dikeringkan di dalam oven dengan suhu $40^{\circ} \mathrm{C}$ selama 18 jam. Setelah itu kelopak bunga kering diblender hingga halus.

\section{Metode Ekstraksi Maserasi}

Serbuk bunga sepatu ditimbang sebanyak 70 gram dan 50 gram kemudian masing - masing dimasukkan ke dalam erlenmayer, ditambahkan $100 \mathrm{ml}$ pelarut etanol $96 \%$, kemudian dihomogenkan. Perendaman dilakukan selama 24 jam pada suhu $4^{\circ} \mathrm{C}$. Setelah 24 jam disaring menggunakan kertas saring Whatman.

\section{Uji Identifikasi Antosianin}

Beberapa tetes ekstrak bunga sepatu dimasukan kedalam tabung reaksi. Kemudian ditambahkan 2 tetes $\mathrm{NaOH} 10 \%$ sehingga terjadi perubahan 
warna. Selanjutnya ditambahkan $\mathrm{HCl}$ pekat sebanyak 2 tetes sehingga warna menjadi merah kembali.

\section{Pembuatan Sediaan Sitologi}

Pembuatan preparat sel menggunakan metode Mandasari dan Nisa (2019) dengan modifikasi. Sampel sel epitel untuk sediaan diambil dari bagian mulut dari daerah mukosa bukal menggunakan cytobrush. Pengerokan dilakukan dalam satu arah sampai terlihat kemerahan didaerah bukal. Selanjutnya hasil kerokan cytobrush dioleskan pada gelas objek.

\section{Pewarnaan}

Pewarnaan diff quik sebanyak 25 preparat sebagai kontrol. Sediaan yang hampir mengering difiksasi dengan metanol \pm 10 kali celupan. Selanjutnya diwarnai dengan cat eosin \pm 10 kali celupan. Langkah berikutnya diwarnai dengan methylen blue \pm 10 kali celupan. Dibilas dengan air. Diamati pada mikroskop.

Slide untuk perlakuan dibagi menjadi lima kelompok :

a. Kelompok A : dicat menggunakan ekstrak bunga sepatu dengan konsentrasi 0,5 gram $/ \mathrm{mL}$ selama 15 menit dan methylen blue.

b. Kelompok B : dicat menggunakan ekstrak bunga sepatu dengan konsentrasi 0,5 gram $/ \mathrm{mL}$ selama 30 menit dan methylen blue.

c. Kelompok C : dicat menggunakan ekstrak bunga sepatu dengan konsentrasi 0,5 gram $/ \mathrm{mL}$ ditambah dengan $\mathrm{HCl}$ selama 30 menit dan methylen blue.

d. Kelompok D : dicat menggunakan ekstrak bunga sepatu dengan konsentrasi 0,7 gram $/ \mathrm{mL}$ selama 15 menit dan methylen blue.

e. Kelompok E : dicat menggunakan ekstrak bunga sepatu dengan konsentrasi 0,7 gram $/ \mathrm{mL}$ selama 30 menit dan methylen blue.

Setelah pengecatan, preparat dibilas dengan air dengan mencelupkan dalam air sebanyak 10-15 kali. Selanjutnya dibiarkan mengering, setelah mengering diamati pada mikroskop dan dilihat kualitas pewarnaan meliputi intensitas warna sitoplasma dan inti sel.

\section{HASIL DAN PEMBAHASAN}

Ekstrak dilakukan pengujian fitokimia secara kualitatif untuk mengetahui ada tidaknya kandungan antosianin dalam ekstrak bunga sepatu. Dari hasil pengujian terjadi perubahan warna menjadi merah setelah dilakukan penambahan dengan $\mathrm{HCl}$ pekat ini menandakan bahwa terdapat kandungan antosianin dalam ekstrak bunga tersebut.

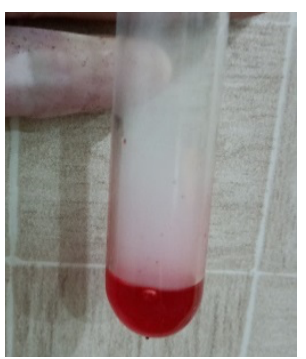

Gambar 1. Hasil Uji Fitokimia Secara Kualitatif

Dalam penelitian ini sampel sediaan diambil dari kerokan mukosa mulut bagian bukal menggunakan alat cytobrush, yang kemudian diapuskan pada objek glass. Kriteria yang dilihat pada sediaan sitologi adalah intensitas warna inti sel dan sitoplasma secara mikroskopis.

Berdasarkan hasil penelitian dapat dilihat bahwa hasil pengecatan menggunakan ekstrak bunga sepatu dengan kualitas yang cukup baik terdapat pada kelompok perlakuan $\mathrm{C}$ dan $\mathrm{D}$ terlihat intensitas warna yang timbul antara inti sel dan sitoplasma cukup baik sehingga inti sel dapat terlihat. Kedua kelompok perlakuan tersebut menggunakan konsentrasi ekstrak bunga sepatu yang berbeda, pada kelompok $\mathrm{C}$ konsentrasi ekstrak yang digunakan lebih rendah dibandingkan dengan kelompok D. Pada kelompok $\mathrm{C}$ menggunakan ekstrak dengan konsentrasi $0,5 \mathrm{gr} / \mathrm{mL}$ serta terdapat penambahan larutan asam $\mathrm{HCl} 1 \%$. Pada kelompok D konsentrasi ekstrak lebih pekat yaitu $0,7 \mathrm{gr} / \mathrm{mL}$ dan tidak ada penambahan asam.

Pada sediaan kontrol terlihat sel terwarnai dengan baik. Pada penelitian ini, ekstrak bunga 
sepatu dengan konsentrasi $0,5 \mathrm{gr} / \mathrm{ml}$ dan 0,7 $\mathrm{gr} / \mathrm{ml}$, serta perbedaan waktu perendaman dan penambahan larutan asam. Pada kelompok perlakuan A dan B dengan konsentrasi 0,5 $\mathrm{gr} / \mathrm{ml}$ dengan waktu perendaman 15 menit dan
30 menit terlihat sel tidak terwarnai dengan baik, kontras antara sitoplasma dan inti sel tidak jelas terlihat dan terdapat banyak artefak pada sediaan.

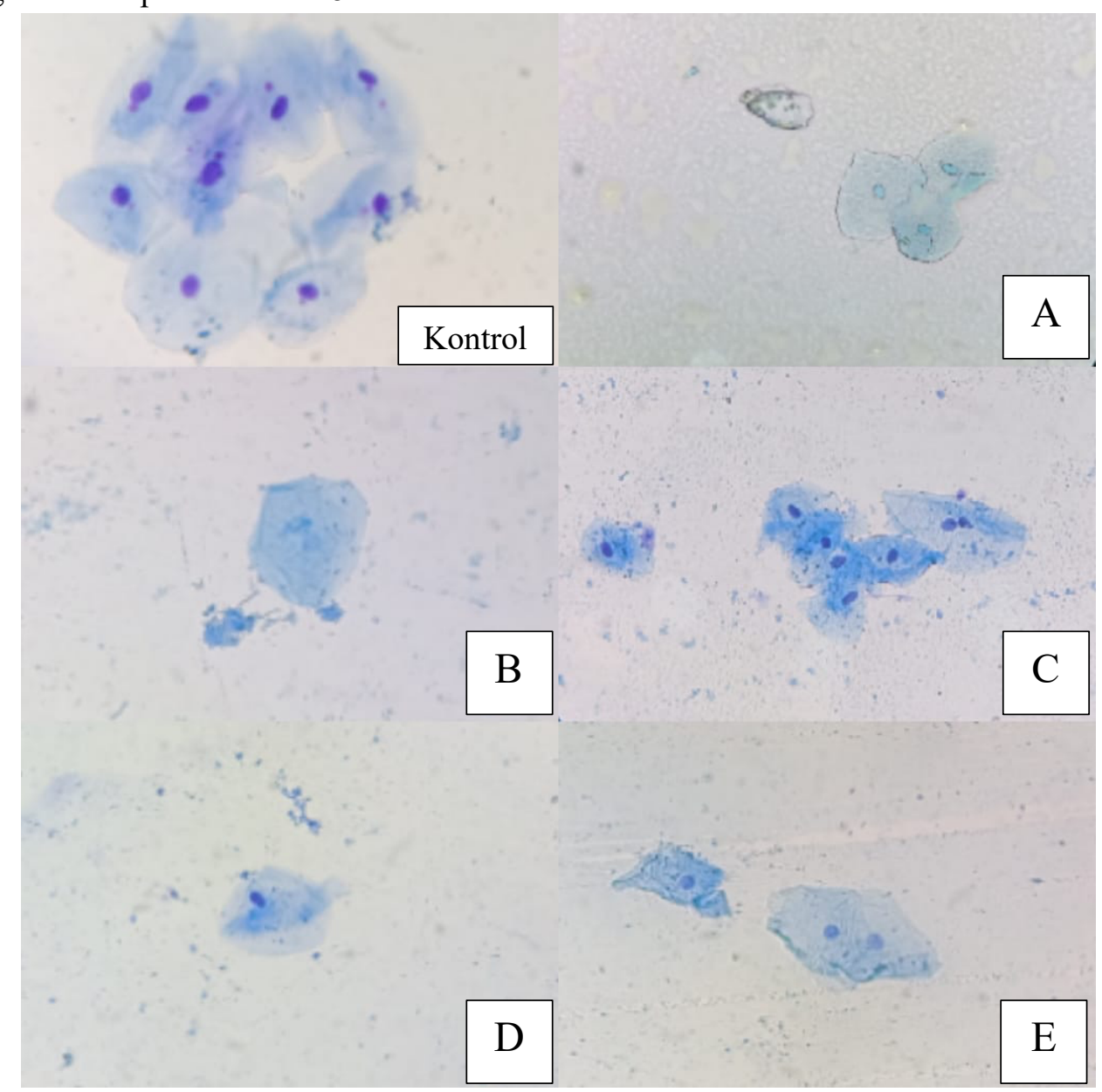

Gambar 2. Hasil pengamatan sediaan kontrol dengan pengecatan Diff-Quick. Gambar A dicat menggunakan ekstrak bunga sepatu dengan konsentrasi 0,5 gram $/ \mathrm{mL}$ selama 15 menit dan methylen blue. Gambar B dicat menggunakan ekstrak bunga sepatu dengan konsentrasi 0,5 gram $/ \mathrm{mL}$ selama 30 menit dan methylen blue. Gambar $\mathrm{C}$ dicat menggunakan ekstrak bunga sepatu dengan konsentrasi 0,5 gram $/ \mathrm{mL}$ ditambah dengan $\mathrm{HCl}$ selama 30 menit dan methylen blue. Gambar D dicat menggunakan ekstrak bunga sepatu dengan konsentrasi 0,7 gram $/ \mathrm{mL}$ selama 15 menit dan methylen blue. Gambar E dicat menggunakan ekstrak bunga sepatu dengan konsentrasi $0,7 \mathrm{gram} / \mathrm{mL}$ selama 30 menit dan methylen blue.

Pada kelompok perlakuan C dimana sediaan diwarnai dengan ekstrak bunga sepatu dengan konsentrasi $0,5 \mathrm{gr} / \mathrm{ml}$ dan ditambahkan larutan asam $\mathrm{HCl} 1 \%$ dengan waktu perendaman 30 menit sel dapat terwarnai dengan baik, inti sel terlihat jelas. Fungsi penambahan $\mathrm{HCl}$ sendiri adalah untuk mempertajam pewarnaan. Ekstrak yang ditambahkan larutan $\mathrm{HCl}$ berubah warna menjadi merah terang dan terlihat pekat. Namun, pada ekstrak dengan konsentrasi yang lebih pekat $0,7 \mathrm{gr} / \mathrm{ml}$ ketika ditambahkan $\mathrm{HCl}$ sel tidak dapat terwarnai. Hal ini dapat terjadi karena ketika konsentrasi ekstrak lebih pekat 
Jurnal SainHealth Vol. 4 No. 2 Edisi September 2020

(C) Fakultas Ilmu Kesehatan Universitas Maarif Hasyim Latif Sidoarjo

p-ISSN : 2548-8333

e-ISSN : 2549-2586

membutuhkan larutan $\mathrm{HCl}$ yang lebih banyak sehingga larutan yang terbentuk akan lebih kental, jika larutan lebih kental atau pekat proses masuknya warna ke dalam sel akan lebih sulit.

Pada kelompok perlakuan D terlihat sel dapat terwarnai dengan baik, inti sel dan sitoplasma terlihat jelas. Konsentrasi ekstrak yang digunakan lebih pekat yaitu $0,7 \mathrm{gr} / \mathrm{ml}$ dan waktu perendaman yaitu 15 menit.

Pada kelompok perlakuan E terlihat sel tidak terwarnai dengan baik. Inti sel tidak terwarnai dengan jelas. Pada kelompok perlakuan ini konsentrasi ekstrak yang digunakan adalah $0,7 \mathrm{gr} / \mathrm{mL}$ dengan waktu perendaman 30 menit, hal demikian terjadi dikarenakan lama waktu pewarnaan yang digunakan tidak sesuai dengan pengenceran ini. Konsentrasi yang digunakan terbilang pekat sehingga saat dilakukan pewarnaan sel sel langsung menyerap zat warna ini dan ketika dilakukan pengecatan dengan cat yang kedua warna tidak bisa terbentuk dengan baik.

Kualitas hasil pewarnaan yang tidak baik dapat disebabkan ketidakstabilan zat warna antosianin yang terkandung dalam ekstrak bunga sepatu tersebut. Antosianin adalah senyawa yang memiliki sifat amfoter yaitu mampu bereaksi dengan basa maupun asam dengan baik dan perubahan warna karena kondisi lingkungan tergantung dari struktur dasar dari posisi ikatanya (Charley, 1970). Kestabilan antosianin dapat dipengaruhi oleh $\mathrm{pH}$, temperatur, ion logam dan oksigen (Niendyah, 2004).

Pada penelitian ini terdapat penambahan $\mathrm{HCl}$ untuk mempertajam pewarnaan serta menarik keluar kelebihan warna yang ada pada sitoplasma dan inti sel. Pada pengecatan hematoksilin eosin penambahan asam digunakan sebagai deferensiasi. Deferensiasi sendiri adalah proses untuk menghilangkan pewarnaan yang berlebihan. Jika tahapan ini tidak dilakukan dengan lengkap maka dapat mengaburkan dan mempengaruhi penyerapan cat selanjutnya (Khristian e. , 2017).

Faktor lain yang dapat menghambat masuknya warna kedalam sel adalah perubahan konsentrasi dari ekstrak, dimana ekstrak yang dibuat menggunakan pelarut etanol $96 \%$ yang mudah menguap sehingga konsentrasi ekstrak menjadi lebih pekat, menyebabkan sel akan kesulitan menyerap zat warna yang terdapat dalam ekstrak bunga sepatu tersebut.

Pada hasil penelitian ini, ekstrak bunga sepatu memiliki potensi untuk mengganti eosin. Akan tetapi, kelemahan pengecatan menggunakan ekstrak tersebut adalah membutuhkan waktu yang lebih lama dibandingkan dengan pengecatan diff quik. Sehingga penelitian lanjutan sangat diperlukan untuk mengoptimalkan waktu pengecatan.

\section{KESIMPULAN}

Berdasarkan hasil penelitian ekstrak bunga sepatu (Hibiscus rosa-sinensis L.) dapat dimanfaatkan sebagai pengganti eosin pada pengecatan diff quik dengan konsentrasi ekstrak bunga sepatu (Hibiscus rosa-sinensis L.) $0,5 \mathrm{gr} / \mathrm{ml}$ yang ditambahkan dengan $\mathrm{HCl}$ $1 \%$ dengan waktu perendaman 30 menit dan konsentrasi ekstrak bunga sepatu (Hibiscus rosa-sinensis L.) dengan konsentrasi $0,7 \mathrm{gr} / \mathrm{ml}$ dengan waktu perendaman 15 menit.

\section{SARAN}

Penelitian ini sangat perlu dilakukan penelitian lanjutan untuk dapat menyempurnakan komposisinya dan waktu pengecatan yang lebih singkat serta daya simpan ekstrak tersebut.

\section{UCAPAN TERIMAKASIH}

Penulis mengucapkan terima kasih kepada bapak ibu pembimbing, ibu Andita Ayu Mandasari, S.Si., M.Biotech dan bapak Setyo Dwi Santoso, S.Si., M.Si. beserta asisten dosen analis laboratorium Fakultas Ilmu 
Kesehatan Universitas Maarif Hasyim Latif Sidoarjo yang telah banyak membantu selama melakukan penelitian.

\section{DAFTAR PUSTAKA}

Agustin, D. and Ismiyati, I., 2015. Pengaruh konsentrasi pelarut pada proses ekstraksi antosianin dari bunga kembang sepatu. Jurnal Konversi, 4(2), pp.9-16.

Charley, H., 1970. Food Science. John Willey and Sons Inc.

Febrianti, F. and Kes, S.M., 2015. Pengaruh Pemberian Ekstrak Etanol Bunga, Daun Dan Akar Kembang Sepatu (Hibiscus rosa sinensis) Terhadap Histologi Testis Mencit (Muss muscullus). WAHANA, 65(2), pp.3341.

Kamal, S.B., 2018. Staining of leishmania donovani promastigotes by natural flower dyes. Pak. J. Biotechnol. Vol, 15(2), pp.299-302.

Khristian, Erick; Inderiati Dewi. 2017. Sitohistoteknologi. Jakarta. 235, 178.

Lukas, H., 2016. Perbandingan Hasil Pemeriksaan Morfologi Spermatozoa Manusia Menggunakan Metode Pewarnaan Papanicolaou, Diff-Quik dan SafraninKristal Violet di RSUD dr. Soetomo Surabaya (Doctoral dissertation, Universitas Airlangga).
Mandasari, A.A. and Nisa, I.C., 2019. Studi komparatif fraksi air susu ibu perah segar dan beku dalam menghambat bakteri enterotoksigenik Escherichia coli. Jurnal Pangan dan Agroindustri, 7(3), pp.1-8.

Niendyah, H., 2004. Efektivitas Jenis Pelarut dan Bentuk Pigmen Antosianin Bunga Kana (Canna coccinea mill.) Serta Aplikasinya pada Produk Pangan. Skripsi. Universitas Brawijaya, Malang.

Sangadji, I., Rijal, M. and Kusuma, Y.A., 2017. Kandungan antosianin di dalam mahkota bunga beberapa tanaman hias. BIOSEL (Biology Science and Education): Jurnal Penelitian Science dan Pendidikan, 6(2), pp.118-128.

Siregar, Y.D.I. and Nurlela, N., 2011. Ekstraksi dan uji stabilitas zat warna alami dari bunga kembang sepatu (Hibiscus rosasinensis L) dan bunga rosela (Hibiscus sabdariffa L). Jurnal Kimia VALENSI, 2(3).

Sridhara, S.U., Raju, S., Gopalkrishna, A.H., Haragannavar, V.C., Latha, D. and Mirshad, R., 2016. Hibiscus: A different hue in histopathology. Journal of Medicine, Radiology, Pathology and Surgery, 2(1), pp.9-11.

Sugumaran, M., Poornima, M. and Sethuvani, S., 2012. Phytochemical and trace element analysis of Hibiscus rosa sinensis Linn and Hibiscus syriacus Linn flowers. Nat Prod, 8, pp.341-345. 